\title{
Ligand-based and structure-based design of novel histone demethylase inhibitors
}

\author{
Luca Carlino $^{1 *}$, Martin Leo Schmitt ${ }^{2}$, Manfred Jung ${ }^{2}$, Wolfgang Sippl ${ }^{1}$ \\ From 8th German Conference on Chemoinformatics: 26 CIC-Workshop \\ Goslar, Germany. 11-13 November 2012
}

The genetic information in eukaryotic cells is organized in a specific structure called chromatin. The basic unit of chromatin is the nucleosome, which consist of four histone proteins and 147 bp of DNA [1]. The N-terminal tails of these proteins contain sited for post-translational modifications directly linked to gene expression. The modifications include acetylation, methylation, phosphorylation, ubiquitinylation, sumoylation and ribosylation. Specific enzymes mediate each modification. LSD1 (Lysine Specific Demethylase I) is one of the histone demethylases, which removes one methyl group from mono- or di-methylated lysine residue. It has recently been demonstrated that androgen receptor (AR)-LSD1 complex demethylates a repressive histone mark (H3K9) promoting genes activation [2]. Experimental data show, also, that LSD1 is strongly expressed in prostate cancers [3]. For these reasons, specific modulation of LSD1 might be a promising therapeutic strategy in tissues where AR has a key physiological role. LSD1 is a flavin-dependent amine oxidase, which shares sequence identity with other flavin dependent amine oxidases like monoamine oxidase (MAO), and polyamine oxidase (PAO). After we analyzed structural differences and similarities among these enzymes several docking studies were evaluated using the available crystal structures of LSD1 and the related oxidases to discover novel LSD1 inhibitors. For the evaluation studies we selected different ligand data sets containing known inhibitors of MAO and PAO. The docking setup that showed the highest accuracy and enrichment factors was selected for virtual screening of LSD1 inhibitors. Preliminary biological data were obtained and will be discussed in the context of the target structure.

\footnotetext{
* Correspondence: carlino.luca@gmail.com

${ }^{1}$ Institut für Pharmazeutische Chemie, Martin-Luther-Universität Halle-

Wittenberg, Halle/Saale 06120, Germany

Full list of author information is available at the end of the article
}

\section{Author details}

${ }^{1}$ Institut für Pharmazeutische Chemie, Martin-Luther-Universität HalleWittenberg, Halle/Saale 06120, Germany. ${ }^{2}$ Institut für Pharmazeutische Wissenschaften, Albert-Ludwigs-Universität Freiburg, Freiburg, 79104, Germany.

\section{Published: 22 March 2013}

\section{References}

1. Luger K, Mäder AW, Richmond RK, Sargent TF, Richmond TJ: Crystal structure of the nucleosome core particle at $2.8 \mathrm{~A}$ resolution. Nature 1997, 389:251-260

2. Metzger E, Wissmann M, Yin N, Müller JM, Schneider R, Peters AHFM, Günther T, Buettner R, Schüle R: LSD1 demethylates repressive histone marks to promote androgen-receptor-dependent transcription. Nature 2005, 437:436-439.

3. Kahl P, Gullotti L, Heukamp LC, Wolf S, Friedrichs N, Vorreuther R, Solleder G, Bastian PJ, Ellinger J, Metzger E, Schüle R, Buettner R: Androgen receptor coactivators lysine-specific histone demethylase 1 and four and a half LIM domain protein 2 predict risk of prostate cancer recurrence. Recurr Cancer Res 2006, 66:11341-11347.

\section{doi:10.1186/1758-2946-5-S1-P41}

Cite this article as: Carlino et al.: Ligand-based and structure-based design of novel histone demethylase inhibitors. Journal of Cheminformatics 2013 5(Suppl 1):P41.

\section{Publish with ChemistryCentral and every scientist can read your work free of charge \\ "Open access provides opportunities to our colleagues in other parts of the globe, by allowing anyone to view the content free of charge." \\ W. Jeffery Hurst, The Hershey Company. \\ - available free of charge to the entire scientific community \\ - peer reviewed and published immediately upon acceptance \\ - cited in PubMed and archived on PubMed Central \\ - yours - you keep the copyright \\ Submit your manuscript here: \\ http://www.chemistrycentral.com/manuscript/

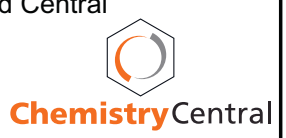

